\title{
Perceptions of adolescents concerning pathological video games use: a qualitative study
}

Isabelle Cisamolo

Universite Paul Sabatier Toulouse III Faculte de Medecine Rangueil

Marie Michel

Universite Paul Sabatier Toulouse III Faculte de Medecine Rangueil

Marie Rabouille

Universite Paul Sabatier Toulouse III Faculte de Medecine Rangueil

Julie Dupouy

Universite Paul Sabatier Toulouse III Faculte de Medecine Rangueil

Emile Escourrou ( $\sim$ emile.escourrou@dumg-toulouse.fr)

Universite Paul Sabatier Toulouse III Faculte de Medecine Rangueil https://orcid.org/0000-0001-5991-8252

\section{Research article}

Keywords: video games, adolescent behaviour, adolescent medicine, adolescent psychiatry, adolescent health, family physicians

Posted Date: June 9th, 2020

DOI: https://doi.org/10.21203/rs.3.rs-32271/v1

License: (c) (7) This work is licensed under a Creative Commons Attribution 4.0 International License. Read Full License

Version of Record: A version of this preprint was published at La Presse Médicale Open on June 1st, 2021. See the published version at https://doi.org/10.1016/j.Ipmope.2021.100012. 


\section{Abstract \\ Background}

Video gaming is one of the main recreational activities of children and adolescents. The American Psychiatric Association and the World Health Organization recently proposed diagnostic criteria for a pathological use of video games. The objective is to explore the perceptions of adolescents concerning pathological video game use.

\section{Methods}

Qualitative study by semi structured individual interviews in the homes of adolescent gamers and non-gamers living in southwest France. The sampling was theoretical. The analysis was carried out using an inductive approach following the phases of thematic analysis. The researchers used triangulation. Collection was concluded when theoretical saturation had been reached.

\section{Results}

17 adolescents aged 10-18 were interviewed between April 2018 and March 2019. The adolescents recognised that video games use can be pathological. Deleterious consequences to physical, mental, and social wellbeing associated with gaming were discussed. Mental health, family and social environments, and the type of game seemed to influence the transition from recreational to pathological video-game use. The adolescents agreed on the need to regulate their gaming, particularly through parental control and self-control.

\section{Conclusions}

Risks and protective factors related to the types of video game, the adolescent, and the environment were identified. Parental support would help lower the risk of pathological gaming.

\section{Background}

Video gaming is one of the main recreational activities of children and adolescents. In 2011, 91\% of American children aged between 2 and 17 played video games [1]. In 2013, 7 out of 10 French people aged between 6 and 65 stated they had played video games within the past six months, of whom $96 \%$ were $10-$ 14-year-olds [2]. Video games are defined as 'any digital recreational practice that includes an interactive dimension and moving images', and refer to a nonhomogeneous array (different media and types of game, diverse profiles of gamers).

The craze for this type of entertainment has raised concerns about potential gaming disorders [3]. In 2013, the American Psychiatric Association (APA) proposed diagnostic criteria for a pathological use of online video games in the 5th edition of the Diagnostic and Statistical Manual of Mental Disorders (DSM5) [4]. In 2018, the World Health Organization (WHO) included online and offline 'gaming disorder' in its 11th Revision of The International Classification of Diseases (ICD-11) [5]. The scientific community believes that more research is needed concerning the diagnostic criteria and possible management of gaming disorders $[3,6]$.

In 2017, a review of 27 studies conducted between 1998 and 2016 found an average prevalence of $4.7 \%$ of players with pathological online gaming habits among a predominantly school-age population [7]. In a two-year longitudinal study, Gentile et al. found a prevalence rate of 7.6-9.9\% of problematic video gaming [8]. According to the study by C. Bonnaire and O. Phan, more than three-quarters of secondary school students interviewed perceive this risk of dependency and the impact of video games on their health [9].

As giving adolescents some responsibility in managing their own health yields the best outcomes [10], their own representations of the risks associated with their gaming habits could be studied.

The objective of this work was to explore the perceptions of adolescents, gamers and non-gamers, concerning pathological video games use.

\section{METHODS}

We conducted a qualitative study with semi-structured interviews of adolescents, gamer and non-gamers, using a thematic analysis approach.

\section{Participant}

The target population was French adolescent gamers and non-gamers, aged from 10 to 19 [11], who had or had not consulted a health professional regarding their use of video games. Subjects who were not able to give their consent to participate in the study were excluded.

\section{Recruitment}

Sources of recruitment were family physicians, hospital-based doctors, and music teachers. The last source allowed a recruitment of adolescents not necessarily included in care plan and who had hobbies. An informational letter was given to each of these contacts, who forwarded an information sheet to the parents. 
The diversification of recruitment sources was designed to obtain a sample as varied as possible. Participants were recruited according to the technique of theoretical sampling [12]. The criteria for subject matter that could lead to varied discussions were established by the researchers based on a literature search conducted before the study. The criteria were age, gender, medical attention linked to video games, gaming habits, family situations.

Once oral agreement was obtained from each adolescent and their parents, the contacts transmitted their details to the researchers carrying out the interviews (M.M. or M.R. - female family medicine residents). The researcher contacted the participant by telephone. She introduced herself as a health researcher conducting research on adolescents' behaviours regarding video games, and set up the interview.

After each interview, a new participant was selected to obtain a different profile.

\section{Data collection}

Semi-structured individual interviews were conducted by one researcher (M.M. or M.R.) and then overseen by two family physician researchers (I.C. and E.E.). A face to face interview in their homes was agreed with the adolescents. The interviews were carried out using an interview guide created by the four researchers, trained in qualitive research (M.M. M.R. and I.C. trained by theoretical teaching with 4 classroom sessions at University Paul Sabatier (Toulouse, France), and E.E. with master's degree (Paris, France)). This guide included open questions on the following themes: personal gaming habits, perception of a good heath, factors of pathological video-game use and health impacts of pathological use. Adolescents were asked to express their own experience or a hypothetical opinion using the example of a friend, if it was difficult to express their personal feelings. The first two interviews enabled the researchers to test out the guide and make improvements.

The data were recorded using a recording device. Observation notes were taken by the researcher in order to anchor the verbal data in the context in which they were gathered.

Data collection ended once the saturation of theoretical data was achieved.

\section{Analysis}

The empirical data (transcriptions, audio recordings, logbooks of observational data) were analysed using an inductive approach following the different phases of a thematic analysis (inspired by the grounded theory) [12]. The coding steps of the verbatim interviews were carried out using Microsoft Excel ${ }^{\circledR}$. Every idea in a subject's citation (verbatim) was noted through an open code. Each open code was attached to a citation and to the author (e.g. Interview $\mathrm{N}^{\circ} 2$ ). This first step was realized at the same time of the data collection.

Then, the conceptual categories were created. These categories summarized in 2 to 4 words the global concept issued from the grouped open codes, with an effort of distancing and conceptualization. This step started after the codification of several interviews in order to have enough material. This step continued after the end of data collection.

The next step was the linking between conceptual categories to define the links observed between them. This step, and those following, were all done on paper, without the use of any software.

Through this linking, a principal theme and 3 to 5 other secondary themes should emerge. We then went back and forth between the empirical and theoretical data to build the themes. The development of themes should permit to answer the research question.

Triangulation was used throughout these phases by the researchers (M.M. M.R. I.C. and E.E.). Triangulation was used to illuminate blind spots in an interpretive analysis.

\section{Ethics}

This research work received approval from the family medicine ethics department of Toulouse (No. 2018-027 - on 16 August 2018). A written informed consent was obtained from each adolescent, and from a parent for participants under 18 years old.

\section{Methods}

We conducted a qualitative study with semi-structured interviews of adolescents, gamer and non-gamers, using a thematic analysis approach.

\section{Participant}

The target population was French adolescent gamers and non-gamers, aged from 10 to 19 [11], who had or had not consulted a health professional regarding their use of video games. Subjects who were not able to give their consent to participate in the study were excluded.

\section{Recruitment}

Sources of recruitment were family physicians, hospital-based doctors, and music teachers. The last source allowed a recruitment of adolescents not necessarily included in care plan and who had hobbies. An informational letter was given to each of these contacts, who forwarded an information sheet to the parents.

The diversification of recruitment sources was designed to obtain a sample as varied as possible. Participants were recruited according to the technique of theoretical sampling [12]. The criteria for subject matter that could lead to varied discussions were established by the researchers based on a literature search 
conducted before the study. The criteria were age, gender, medical attention linked to video games, gaming habits, family situations.

Once oral agreement was obtained from each adolescent and their parents, the contacts transmitted their details to the researchers carrying out the interviews (M.M. or M.R. - female family medicine residents). The researcher contacted the participant by telephone. She introduced herself as a health researcher conducting research on adolescents' behaviours regarding video games, and set up the interview.

After each interview, a new participant was selected to obtain a different profile.

\section{Data collection}

Semi-structured individual interviews were conducted by one researcher (M.M. or M.R.) and then overseen by two family physician researchers (I.C. and E.E.). A face to face interview in their homes was agreed with the adolescents. The interviews were carried out using an interview guide created by the four researchers, trained in qualitive research (M.M. M.R. and I.C. trained by theoretical teaching with 4 classroom sessions at University Paul Sabatier (Toulouse, France), and E.E. with master's degree (Paris, France)). This guide included open questions on the following themes: personal gaming habits, perception of a good heath, factors of pathological video-game use and health impacts of pathological use. Adolescents were asked to express their own experience or a hypothetical opinion using the example of a friend, if it was difficult to express their personal feelings. The first two interviews enabled the researchers to test out the guide and make improvements.

The data were recorded using a recording device. Observation notes were taken by the researcher in order to anchor the verbal data in the context in which they were gathered.

Data collection ended once the saturation of theoretical data was achieved.

\section{Analysis}

The empirical data (transcriptions, audio recordings, logbooks of observational data) were analysed using an inductive approach following the different phases of a thematic analysis (inspired by the grounded theory) [12]. The coding steps of the verbatim interviews were carried out using Microsoft Excel ${ }^{\circledR}$.

Every idea in a subject's citation (verbatim) was noted through an open code. Each open code was attached to a citation and to the author (e.g. Interview $\mathrm{N}^{\circ} 2$ ). This first step was realized at the same time of the data collection.

Then, the conceptual categories were created. These categories summarized in 2 to 4 words the global concept issued from the grouped open codes, with an effort of distancing and conceptualization. This step started after the codification of several interviews in order to have enough material. This step continued after the end of data collection.

The next step was the linking between conceptual categories to define the links observed between them. This step, and those following, were all done on paper, without the use of any software.

Through this linking, a principal theme and 3 to 5 other secondary themes should emerge. We then went back and forth between the empirical and theoretical data to build the themes. The development of themes should permit to answer the research question.

Triangulation was used throughout these phases by the researchers (M.M. M.R. I.C. and E.E.). Triangulation was used to illuminate blind spots in an interpretive analysis.

\section{Ethics}

This research work received approval from the family medicine ethics department of Toulouse (No. 2018-027 - on 16 August 2018). A written informed consent was obtained from each adolescent, and from a parent for participants under 18 years old.

\section{Results}

\section{Participants}

17 adolescents were recruited between April 2018 and March 2019 in south-west France (see Table 1). Seven of the adolescents contacted declined to take part in the study, without providing any reason.

The adolescents recruited were aged between 10 and 18; the average age was 14.2. The sample comprised 4 girls and 13 boys, all in school; two were nongamers. Three adolescents had been taken to see a health care professional regarding their gaming habits, which their parents saw as problematic.

Table 1: Characteristics of the sample of adolescents interviewed in 2018-2019 to explore the perception of pathological video game use. 


\begin{tabular}{|c|c|c|c|c|c|c|c|c|c|c|c|c|}
\hline & Age & Gender & Schooling* & $\begin{array}{l}\text { Medical } \\
\text { attention }\end{array}$ & Media & $\begin{array}{l}\text { Game } \\
\text { mode }\end{array}$ & $\begin{array}{l}\text { Game } \\
\text { mode }\end{array}$ & $\begin{array}{l}\text { Type of } \\
\text { game** }\end{array}$ & $\begin{array}{l}\text { Time } \\
\text { playing*** }\end{array}$ & $\begin{array}{l}\text { Parental } \\
\text { Control }\end{array}$ & $\begin{array}{l}\text { Family } \\
\text { Structure }\end{array}$ & $S$ \\
\hline & & & & $\begin{array}{l}\text { video } \\
\text { games }\end{array}$ & & $\begin{array}{l}\text { Online } \\
\text { or } \\
\text { offline }\end{array}$ & $\begin{array}{l}\text { Single or } \\
\text { multiplayer }\end{array}$ & & (hours/day) & & & \\
\hline \multirow[t]{2}{*}{$\begin{array}{l}\text { Interview } \\
1\end{array}$} & \multirow[t]{2}{*}{16} & \multirow[t]{2}{*}{ Male } & \multirow[t]{2}{*}{$\begin{array}{l}\text { Year 12, } \\
\text { Science }\end{array}$} & \multirow[t]{2}{*}{ No } & \multirow[t]{2}{*}{$\begin{array}{l}\mathrm{PC}- \\
\text { Console }\end{array}$} & \multirow{2}{*}{$\begin{array}{l}\text { Online } \\
\text { and } \\
\text { offline }\end{array}$} & \multirow[t]{2}{*}{$\begin{array}{l}\text { Single and } \\
\text { multiplayer }\end{array}$} & \multirow[t]{2}{*}{$\begin{array}{l}\text { Adventure - } \\
\text { Shooting }\end{array}$} & & \multirow[t]{2}{*}{ No } & \multirow[t]{2}{*}{ Biparental } & \multirow[t]{2}{*}{4} \\
\hline & & & & & & & & & $\begin{array}{l}\text { W/d: } 0 \mathrm{~h} \\
\text { W/e: } 4 \mathrm{~h}\end{array}$ & & & \\
\hline \multirow{3}{*}{$\begin{array}{l}\text { Interview } \\
2\end{array}$} & \multirow[t]{3}{*}{12} & \multirow[t]{3}{*}{ Male } & \multirow[t]{3}{*}{ Year 7} & \multirow[t]{3}{*}{ No } & \multirow{2}{*}{$\begin{array}{l}\mathrm{PC}- \\
\text { Console }\end{array}$} & Online & Single & \multirow{2}{*}{$\begin{array}{l}\text { Adventure - } \\
\text { Shooting }\end{array}$} & Daily & \multirow[t]{3}{*}{ No } & \multirow[t]{3}{*}{ Biparental } & \multirow[t]{3}{*}{2} \\
\hline & & & & & & \multirow{2}{*}{ Offline } & \multirow{2}{*}{ Multiplayer } & & W/d: $1 \mathrm{~h}$ & & & \\
\hline & & & & & $\begin{array}{l}\text { Tablet - } \\
\text { Smartphone }\end{array}$ & & & Strategy & W/e: $5 \mathrm{~h}$ & & & \\
\hline \multirow{2}{*}{$\begin{array}{l}\text { Interview } \\
3\end{array}$} & 15 & Male & Year 11 & No & $\mathrm{PC}-$ & Online & Single & Adventure - & Daily & Yes & Biparental & 4 \\
\hline & & & & & & Offline & Multiplayer & Combat & $\begin{array}{l}\text { W/d: } \\
\text { 3hW/e: } 5 \mathrm{~h}\end{array}$ & & & \\
\hline $\begin{array}{l}\text { Interview } \\
4\end{array}$ & 17 & Male & $\begin{array}{l}\text { Technical } \\
\text { Tertiary }\end{array}$ & Yes & $\begin{array}{l}\text { Console - } \\
\text { Tablet }\end{array}$ & Online & Single & Adventure - & Daily & Yes & Biparental & 4 \\
\hline & & & Studies & & & Offline & Multiplayer & & $\begin{array}{l}\text { W/d: } 2.5 \mathrm{~h} \\
\text { W/e: } 3.5\end{array}$ & & & \\
\hline $\begin{array}{l}\text { Interview } \\
5\end{array}$ & 11 & Male & Year 6 & No & Console - & Offline & Single & Adventure - & Daily & Yes & Biparental & 4 \\
\hline & & & & & & & Multiplayer & & $\begin{array}{l}\text { W/d: } 45 \mathrm{~min} \\
\text { W/e: } 45 \mathrm{~min}\end{array}$ & & & \\
\hline $\begin{array}{l}\text { Interview } \\
6\end{array}$ & 15 & Female & Year 11 & No & - & - & - & - & - & - & Biparental & 2 \\
\hline $\begin{array}{l}\text { Interview } \\
7\end{array}$ & 16 & Female & $\begin{array}{l}\text { Year 13, } \\
\text { Science }\end{array}$ & No & $\begin{array}{l}\mathrm{PC}- \\
\text { Console - }\end{array}$ & Offline & Single & $\begin{array}{l}\text { Management } \\
\text { - Platform }\end{array}$ & Weekly & Yes & Biparental & 2 \\
\hline & & & & & Smartphone & & Multiplayer & & $\begin{array}{l}\text { W/d: } \\
\text { 4hW/e: } 0 \mathrm{~h}\end{array}$ & & & \\
\hline $\begin{array}{l}\text { Interview } \\
8\end{array}$ & 14 & Male & Year 10 & Yes & Console & Online & Multiplayer & $\begin{array}{l}\text { Shooting - } \\
\text { Sport }\end{array}$ & Weekly & Yes & $\begin{array}{l}\text { Single } \\
\text { parent }\end{array}$ & 3 \\
\hline & & & & & & & & & $\begin{array}{l}\text { W/d: } 5 \mathrm{~h} \\
\text { W/e: } 5 \mathrm{~h}\end{array}$ & & Divorce & \\
\hline $\begin{array}{l}\text { Interview } \\
9\end{array}$ & 13 & Male & Year 10 & No & Console & Online & Multiplayer & $\begin{array}{l}\text { Shooting - } \\
\text { Sport }\end{array}$ & & Yes & Biparental & 2 \\
\hline & & & & & & & & & $\begin{array}{l}\text { W/d: } 2 \mathrm{~h} \\
\text { W/e: } 8 \mathrm{~h}\end{array}$ & & & \\
\hline $\begin{array}{l}\text { Interview } \\
10\end{array}$ & 18 & Male & $\begin{array}{l}\text { Year 13, } \\
\text { STAY }\end{array}$ & No & $\mathrm{PC}-$ & Online & Single & MOBA - & Weekly & No & Biparental & 2 \\
\hline & & & & & & Offline & Multiplayer & & $\begin{array}{l}\text { W/d: } 0 \mathrm{~h} \\
\text { W/e: } 8 \mathrm{~h}\end{array}$ & & & \\
\hline $\begin{array}{l}\text { Interview } \\
11\end{array}$ & 17 & Male & $\begin{array}{l}\text { Year 13, } \\
\text { ES }\end{array}$ & No & $\begin{array}{l}\text { Console - } \\
\text { Smartphone }\end{array}$ & Offline & Multiplayer & Adventure & Occasional & No & Blended & 3 \\
\hline & & & & & & & & & & & Divorce & \\
\hline $\begin{array}{l}\text { Interview } \\
12\end{array}$ & 13 & Female & Year 9 & No & - & - & - & - & - & - & Biparental & 3 \\
\hline Interview & 13 & Male & Year 9 & No & Console - & Online & Single & Shooting & Monthly & No & Biparental & 2 \\
\hline & & & & & Smartphone & Offline & Multiplayer & & & & & \\
\hline $\begin{array}{l}\text { Interview } \\
14\end{array}$ & 14 & Male & Year 10 & No & $\begin{array}{l}\text { Console - } \\
\text { Tablet }\end{array}$ & Offline & Multiplayer & $\begin{array}{l}\text { Adventure - } \\
\text { Role Playing }\end{array}$ & & Yes & $\begin{array}{l}\text { Single } \\
\text { parent }\end{array}$ & 2 \\
\hline & & & & & & & & & $\begin{array}{l}\text { W/d: } 0 \mathrm{~h} \\
\text { W/e: } 1 \text { to } \\
\text { 10h }\end{array}$ & & & \\
\hline $\begin{array}{l}\text { Interview } \\
15\end{array}$ & 10 & Male & Year 6 & No & Console - & Online & Single & Role Playing & Weekly & Yes & Single & 2 \\
\hline & & & & & & Offline & Multiplayer & & $\begin{array}{l}\text { W/d: } 0 \mathrm{~h} \\
\text { W/e: } 1.5 \mathrm{~h}\end{array}$ & & Divorce & \\
\hline $\begin{array}{l}\text { Interview } \\
16\end{array}$ & 14 & Male & Year 10 & Yes & PC - & Online & Single & Adventure - & Daily & Yes & Single & 2 \\
\hline & & & & & $\begin{array}{l}\text { Tablet - } \\
\text { Smartphone }\end{array}$ & Offline & Multiplayer & Platform & $\begin{array}{l}\text { W/d: } \\
\text { 3hW/e: 7h }\end{array}$ & & Divorce & \\
\hline Interview & 14 & Female & Year 10 & No & Console & Online & Single & Shooting & Daily & No & Biparental & 4 \\
\hline & & & & & & Offline & Multiplayer & & $\begin{array}{l}\text { W/d: } 0-3 h \\
\text { W/e: } 5 \mathrm{~h}\end{array}$ & & & \\
\hline
\end{tabular}


* S: Scientific; BTS: Superior Technician Certificate; STAV: Agronomy Sciences and Technology; ES: Economics and Social Sciences

** MOBA: Multiplayer Online Battle Arena (Typology of video games)

*** W/d: Weekday W/e: Weekend Weekly: Playing video games at least once a week, but not daily

*** Socio-professional categories using French nomenclature:

1 : Farmers, 2 : Artisans, retailers, and business leaders, 3 : Managers and higher intellectual professions, 4 : Intermediate professions,

5: Employees, 6 : Manual workers, 7 : Retirees, 8: Other people without professional activity

The interviews lasted between 20 and 103 minutes and the average duration was 42 minutes and 15 seconds.

The analysis of these 17 interviews generated four major themes:

- adolescents' descriptions of pathological video games use,

- the effects of video games on health,

- precipitating factors in the transition from recreational to pathological use,

- protective factors in the transition from recreational to pathological use.

Pathological video games use and its characteristics

Adolescents recognised the concept of pathological use of video games. These characteristics, as defined the adolescents, were: significant playing time, neglecting the real world, confusion between the virtual world and the real world, and symptoms similar to those linked to substance use.

\section{Significant playing time}

Significant playing time and daily gaming were the determining elements of this pathological use. The adolescents used the term 'too much' to describe an excessive and harmful habit in which one loses control of one's gaming habit and has difficulty stopping. Significant playing time fostered a dangerous identification with the characters.

'If you play for too long too often (...) it's a sure thing that you're going to have serious problems.' Interview 2.

\section{Neglecting the real world and confusion with the virtual world}

The game became the dominant activity in the life of the gamer, impoverishing his or her other activities. Friends and families were ignored, and the obligations of daily life neglected. The adolescents referred to social isolation in the real world contrasted with a rich virtual social life.

'In your bubble (...) you only think (...) about video games (...) you don't pay attention to what's around you' Interview 14.

Gamers with pathological playing habits confused the real and virtual worlds. Therefore, they could transpose actions from the virtual into the real world, risking violent acts or sexually dysfunctional behaviours. This confusion was enhanced by isolation, the gamer having a poor understanding of the real world. The realistic nature of a game also facilitated this confusion.

\section{Similarities in their discussions with issues of substance abuse}

For the adolescents, pathological video games use shared symptomatic similarities with issues linked to substance abuse, which was thought to be more dangerous.

The gamer could no longer do without video games. This loss of control of the freedom to consume manifested in withdrawal symptoms, tolerance, and cravings. Significant in-game purchases could then be made.

'It's addictive; the more you play, the more you want to play' Interview 7.

The effects of video games on health

The adolescents envisaged benefits as well as risks to their health from their gaming habits. The risks arose from abnormal and often excessive use. Pathological use could have consequences on physical health: eyesight, osteo-articular, and metabolic issues; and on mental health by impacting self-esteem, mood, and social relationships.

'There is obviously an impact on our life, either positive or negative' Interview 3. 
Loosing, or peer judgement of their performance, was a source of frustration, anger, and sadness. Sometimes irritability was uncontrollable, which could be a source of lowered self-worth and social isolation.

'I am him, if he is rubbish, then so am I' Interview 10.

Identity issues

By trying to imitate an idolised character, the gamer loses his or her personality and individuality and appropriates the shortcomings of his or her avatar. The danger resides in the identification with 'bad characters' and the risk of committing regrettable acts (violence, substance abuse). This led to social isolation which was considered a danger.

'That prevents us from showing who we really are (...) we imitate a character' Interview 3.

Family conflict

Video games caused intra-family conflicts. Competition and restrictive parental controls exacerbated the conflict.

'I was in a fairly addictive phase (...) so there were problems between my parents and me' Interview 4.

\section{Risk factors in the transition to a pathological use of video games}

Type of game

The type of game was blamed, especially war games, action games, MMORPG (Massively Multiplayer Online Role-Playing Game), and games with the most social and competitive elements. Portable devices (console, smartphone) that enable gamers to play were identified as a risk factor for pathological use. The omnipresence of video games in contemporary society (advertising, special events) was thought to encourage gaming.

Adolescent's issues with social relationships

Introverted subjects appeared to be at greater risk. Their challenges with social integration in the real world explained their investment in the virtual world. Certain gamers' motivations were linked to pathological use: competition, performance, and seeking out wellbeing.

'They've got problems in their life, so they take refuge in games to be able to feel better' Interview 16.

A deleterious family and social environment

A complex family structure (divorce, death of a parent, intra-family conflict) was associated with pathological use. An environment without friends or in an isolated location was compensated by a great investment in the virtual world.

\section{Protective factors in the transition to pathological video games use}

Protective tools specific to video games

According to the respondents, adopting systems to manage the amount of time spent gaming reduced the risk of pathological use. Complying with PEGI (Pan European Game Information) could avoid problematic use. Some of the adolescents suggested choosing less addictive games.

'The console must shut down automatically (...) you should have to wait some time before turning it back on' Interview 10.

\section{Self-control by adolescents}

The adolescents agreed on the need to regulate their habit. An adolescent must be conscious of the risks linked to pathological video game use. 'Self-imposed limits' Interview 6.

\section{A protective family and social environment}

The main protective factor referred to was parental control, which should be seen as a support mechanism that changes with the maturity of the adolescent and enables the adolescent to attain self-control based on dialogue and trust. Restrictive measures were worked around.

'Parents are there to support you but also after a while you have to find out by yourself and, in the end, learn from your own mistakes.' Interview 11.

Outings and non-digital activities also helped limit gaming and the risk of a pathological video games use.

\section{Discussion}

Adolescents interviewed recognised that pathological video games use can have deleterious impacts on their physical and mental health. The principal characteristics of this pathological use were significant playing time, neglecting the real world, and confusion between the real and virtual worlds. The adolescents described the precipitating and protective factors linked to the type of game, the adolescent, and his or her environment. Figure 1

A critical view of adolescents' gaming habits

Page 7/12 
The criteria referred to by the adolescents to define a pathological gamer were for the most part congruent with those of the DSM-5 [4] and the ICD-11 [5]. Figure 2

Figure 2: Relationship between the criteria proposed for diagnosing pathological video games use in accordance with the ICD-11 and DSM- 5 classifications and the criteria suggested by the adolescents interviewed.

The analysis of a questionnaire given to French secondary school students in 2017 identified three principal elements: 'not knowing how to stop gaming', 'not meeting your obligations', and 'doing nothing but gaming' [9]. A study based on a focus group comprising young adult gamers found a significant consensus on 'changes to how you function and clinically meaningful distress'. Compared to our study, isolation and neglecting reality were also addressed [13].

The notion of craving came up during our interviews. This criterion is not included in either the DSM- 5 or the ICD-11 for addiction to video games, it is only referenced in issues arising from substance abuse and is not found in behavioural addictions [4].

Excessive time spent gaming would not be sufficient to characterise pathological use. Care should be taken in considering excessive gaming as pathological [14]. Engagement (enriching and consistent with enthusiasm) should be distinguished from pathological use (having personal, professional, and/or socially negative consequences) to avoid pathologising what is a non-problematic activity in the majority of cases [15]. Wood adduces the example of reading or practising a musical instrument to illustrate this point: Spending lots of time on either of those is socially acceptable, and not in and of itself an addiction [16].

\section{The precipitating factors in pathological use}

The risk factors highlighted for the pathological video games use could be incorporated into the description of an addictive process described in accordance with the trivariate model: 'encountering a product, personality, and a socio-cultural moment'[17].

The product

As found in our results, some structural characteristics of video games can be associated with pathological use: the systems of reward, the creation of a gaming habit (daily quests...), and looking for "flow": a state of intense satisfaction reached during an activity [18,19].

MMORPGs, games with a high degree of competitiveness or sociability, and action and war games are characterised by a persistent and perpetual universe. The rich social organisation creates the feeling of belonging to a group. Immersion is important [20]. Labelling systems like the PEGI in Europe provide instructive help in using video games. However, one study argues that PEGI could help make forbidden games more attractive [21].

\section{Personality}

Some personality traits and psychological profiles are also linked to pathological use. Introversion, shyness, and impulsiveness are most often associated with pathological uses [22,23]. Pathological gamers tend to have lower self-esteem [21]. For some authors, depressive moods and anxiety issues could also be a predictive factor in the pathological video games use [24]. Finally, Attention Deficit Hyperactivity Disorder (ADHD) or Attention Deficit Disorder (ADD) are also known as comorbidities found in addiction phenomena [25].

\section{The socio-cultural moment}

The adolescents interviewed highlighted the importance of parental control. Single-parent or blended families could be associated with pathological behaviours [26]. Gamers with pathological use have weak relationships and family cohesion and more family conflicts [27]. The absence of parental controls or a negative parental attitude could be associated with pathological use [26]. The American Academy of Pediatrics recommends that parents be involved in their children's use of media, particularly by ensuring that they have periods without media use, and access to other creative activities [3]

\section{Strengths and weaknesses of the study}

Strengths of the study

This is an original work anchored in current events. The internal validity of the study was ensured by the reflective work carried out throughout the study and by adherence to triangulation of the data and the researchers. The characteristics of the population studied were diverse regarding age, gender, medical attention linked to video games, gaming habits, family situations.

Weaknesses of the study

Sometimes the participants knew about the family medicine resident statute of researchers: it was disclosed during the interview at the request of the adolescent. This might have changed what was discussed. Few girls were recruited but the ratio is consistent with the literature: girls play video games less than boys [8].

\section{Role of family physicians}

Adolescents could use primary health care for both psychosocial difficulties and somatic concerns [28]. In case of emotional or behaviours problems, the family physician has to be sincere, ensure confidentiality and put forward the right questions [29]. This attitude could be also employed for adolescents with pathological video game use.

\section{Conclusion}


The adolescents in this study recognised the transition from a recreational use to a pathological use with consequences for their health and identified parents as resources to help them control their gaming.

The scientific community continues to debate the definition of pathological video games use. Using common diagnostic criteria would enable a better understanding of the phenomenon, challenging up until now because of the lack of consensus; and comparability of results.

\section{Abbreviations}

APA

American Psychiatric Association

ADD

Attention Deficit Disorder

ADHD

Attention Deficit Hyperactivity Disorder

DSM-5

Diagnostic and Statistical Manual of Mental Disorders

ICD-11

The International Classification of Diseases

MMORPG

Massively Multiplayer Online Role-Playing Game

PEGI

Pan European Game Information

WHO

World Health Organization

\section{Declarations}

Ethics Approval and Consent to Participate This research work has been approved by the family medicine ethics department of Midi Pyrenees - France (16 August 2018 - No. 2018-027). A written informed consent was obtained from each adolescent, and from a parent for participants under 18 years old.

Consent for publication A parental authorisation and consent form were signed by each adolescent and one of their two parents with a mention regarding publication.

Availability of data and material On demand

Competing interests The authors declare that they have no competing interests

\section{Funding None}

Authors' contributions All authors contributed to the study conception and design. Material preparation, data collection and analysis were performed by I.C., M.M., M.R. under the supervision of J.D. and E.E. The first draft of the manuscript was written by I.C. and E.E. and all authors commented on previous versions of the manuscript. All authors read and approved the final manuscript.

Acknowledgement The authors thank all those who agreed to take part in the interviews.

\section{References}

1. The National Purchase Diary Group (2001) https://www.afjv.com/news/233_\%20kids-and-gaming-2011.htm. Accessed 30 January 2020.

2. Centre National du Cinéma et de l'image animée (CNC) (2014) https://www.cnc.fr/jeu-video/etudes-et-rapports/etudes-prospectives/les-pratiques-deconsommation-de-jeux-video-des-francais_304289 Accessed 30 January 2020.

3. Gentile DA, Bailey K, Bavelier D, et al (2017) Internet gaming disorder in children and adolescents. Pediatrics 140;S81. http://doi.org/10.1542/peds.2016$1758 \mathrm{H}$

4. American Psychiatric Association (2018) https://www.psychiatry.org/psychiatrists/practice/dsm. Accessed 30 January 2020.

5. World Health Organization (2019) https://icd.who.int/dev11/I-m/en\#/http\%3a\%2f\%2fid.who.int\%2ficd\%2fentity\%2f1448597234 Accessed 6 February 2020.

6. Colder Carras M, Kardefelt-Winther D (2018) When addiction symptoms and life problems diverge: a latent class analysis of problematic gaming in a representative multinational sample of European adolescents. Eur Child Adolesc Psychiatry 27:513-25. http://doi.org/10.1007/s00787-018-1108-1

7. Feng W, Ramo DE, Chan SR, et al (2017) Internet gaming disorder: trends in prevalence 1998-2016. Addict Behav 75:17-24. http://doi.org/10.1016/j.addbeh.2017.06.010

8. Gentile DA, Choo H, Liau A, et al (2011) Pathological video game use among youths: a two-year longitudinal study. Pediatrics 127(2):e319-e329. http://doi.org/10.1542/peds.2010-1353 
9. Bonnaire C, Phan O (2017) Negative perceptions of the risks associated with gaming in young adolescents: an exploratory study to help thinking about a prevention program. Arch Pediatr 24(7):607-17. http://doi.org/ 10.1016/j.arcped.2017.04.006

10. Robertson S, Pryde K, Evans K (2014) Patient involvement in quality improvement: is it time we let children, young people and families take the lead? Arch Dis Child Educ Pract Ed 99:23-7. http://doi.org/ 10.1136/archdischild-2013-304327

11. World Health Organization https://www.who.int/maternal_child_adolescent/topics/adolescence/dev/fr/ Accessed 30 January 2020.

12. Glaser BG, Strauss AL (1967) The Discovery of Grounded Theory: Strategies for Qualitative Research. Aldine Transaction, London.

13. Colder Carras M, Porter AM, et al (2018) Gamers' insights into the phenomenology of normal gaming and game "addiction": A mixed methods study. Comput Hum Behav 79:238-46. http://doi.org/10.1016/j.chb.2017.10.029

14. Petry NM. Commentary on Van Rooij, et al (2011) 'Gaming addiction'- a psychiatric disorder or not? Addiction 106(1):213-4. http://doi.org/ $10.1111 / \mathrm{j} .1360-0443.2010 .03132 . x$

15. Griffiths M (2008) Diagnosis and management of video game addiction. New Dir Addict Treat Prev 12:27-41.

16. Wood RTA (2008) Problems with the concept of video game "addiction": some case study examples. Int J Ment Health Addict 6(2):169-78. https://doi.org/10.1007/s11469-007-9118-0

17. Guillou-Landréat M, Grall-Bronnec M, Vénisse JL (2012) Addictions comportementales. Presse Médicale 41(12, Part 1):1271-5. https://doi.org/10.1016/j.lpm.2012.07.024

18. Chou TJ, Ting CC (2003) The role of flow experience in cyber-game addiction. Cyberpsychology Behav Impact Internet Multimed Virtual Real Behav Soc 6(6):663-75. http://doi.org/10.1089/109493103322725469

19. Khang H, Kim JK, Kim Y (2013) Self-traits and motivations as antecedents of digital media flow and addiction: the Internet, mobile phones, and video games. Comput Hum Behav 29(6):2416-24. https://doi.org/10.1016/j.chb.2013.05.027

20. Na E, Choi I, Lee TH, et al (2017) The influence of game genre on Internet gaming disorder. J Behav Addict 6(2):248-55. http://doi.org/10.1556/2006.6.2017.033

21. Bijvank MN, Konijn EA, Bushman BJ, et al (2009) Age and violent-content labels make video games forbidden fruits for youth. Pediatrics $123(3): 870-6$. http://doi.org/10.1542/peds.2008-0601

22. Paulus FW, Ohmann S, von Gontard A, et al (2018) Internet gaming disorder in children and adolescents: a systematic review. Dev Med Child Neurol 60(7):645-59. http://doi.org/10.1111/dmcn.13754

23. Lau C, Stewart SL, Sarmiento C, Saklofske DH, Tremblay PF (2018) Who Is at Risk for Problematic Video Gaming? Risk Factors in Problematic Video Gaming in Clinically Referred Canadian Children and Adolescents. Multimodal Technologies Interact 2(2),19. https://doi.org/10.3390/mti2020019

24. Torres-Rodríguez A, Griffiths MD, Carbonell X, et al (2018) Internet gaming disorder in adolescence: Psychological characteristics of a clinical sample. J Behav Addict 7(3):707-18. http://doi.org/10.1556/2006.7.2018.75

25. Stenseng F, Hygen BW, Wichstrøm L (2019) Time spent gaming and psychiatric symptoms in childhood: cross-sectional associations and longitudinal effects. Eur Child Adolesc Psychiatry [published online ahead of print, 2019 Sep 6] http://doi.org/10.1007/s00787-019-01398-2

26. Schneider LA, King DL, Delfabbro PH (2017) Family factors in adolescent problematic Internet gaming: a systematic review. J Behav Addict 6(3):321-33. http://doi.org/10.1556/2006.6.2017.035

27. Bonnaire C, Phan O (2017) Relationships between parental attitudes, family functioning and Internet gaming disorder in adolescents attending school. Psychiatry Res 255:104-10. http://doi.org/10.1016/j.psychres.2017.05.030

28. Kekkonen VK, Kivimäki P, Valtonen H, et al (2015) Psychosocial problems in adolescents associated with frequent health care use. Fam Pract 32(3):30510. http://doi.org/10.1093/fampra/cmu090

29. Tudrej B, Heintz AL, Ingrand P, et al (2016) What do troubled adolescents expect from their GPs? Eur J Gen Pract 22(4):247-54. http://doi.org/10.1080/13814788.2016.1216541.

\section{Figures}




\section{Pathological video games use according to the participating adolescents}

Significant playing time

Neglecting the real world and confusion with the virtual world Comparison with an addiction "to drugs"

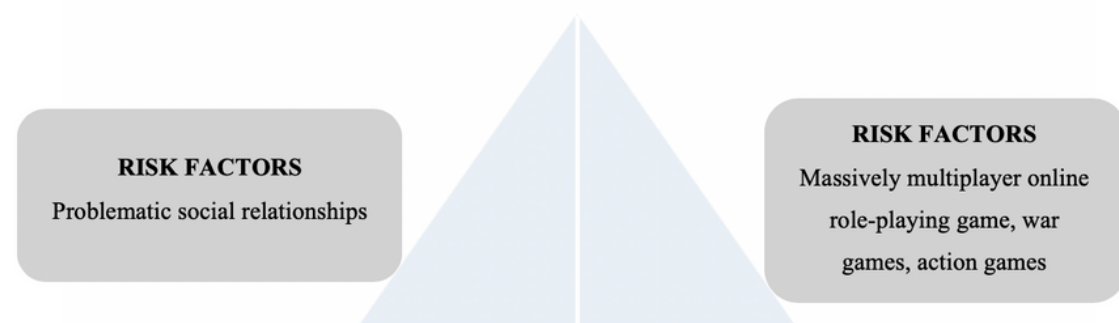

PROTECTIVE FACTORS

Self-control by the adolescent.

Awareness of the potential risks
PROTECTIVE FACTORS

Limiting gaming time, preregulated by the gaming media :

Pan European Game Information

\section{ENVIRONMENT}

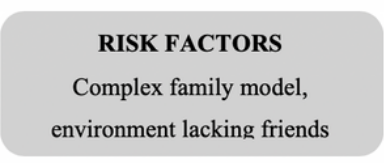

PROTECTIVE FACTORS

Supportive parental control

\section{Figure 1}

Principal results of the perception of adolescents regarding a pathological video game use 


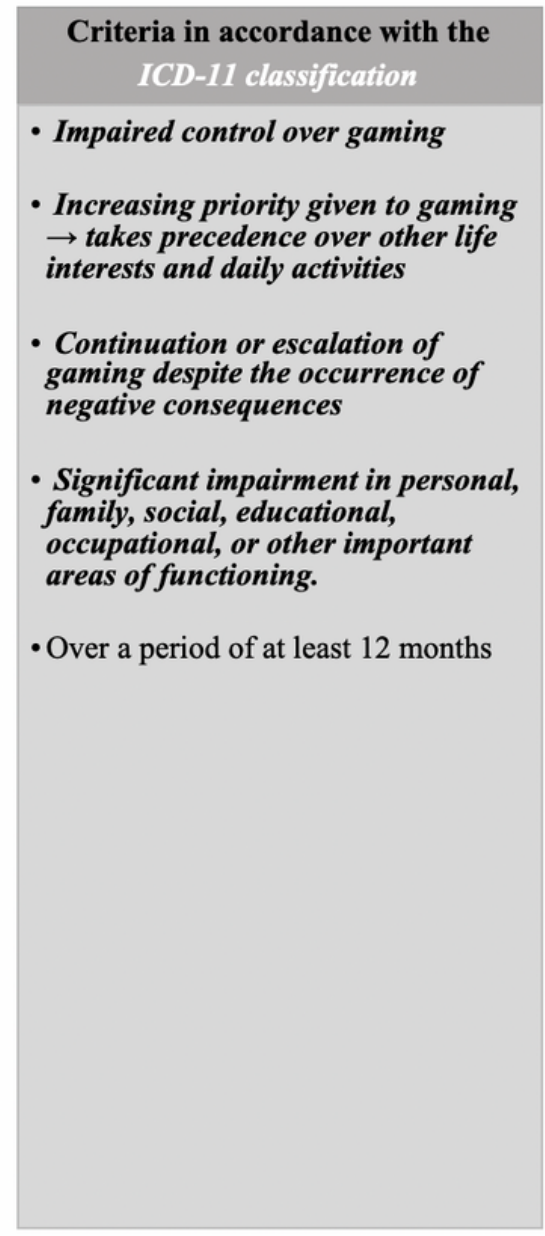

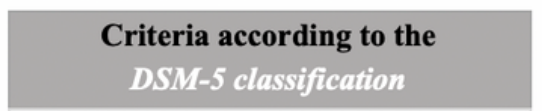

- Preoccupations by online games

-Withdrawal symptoms (irritability, anxiety, or sadness)

\section{- Tolerance}

- Failed attempts at controlling participation in games

- Loss of interest in previous leisure and entertainment activities

- Excessive online gaming followed by psychosocial problems

- Lying to family, therapists, or others about the amount of time spent online gaming

- Internet gaming to escape or alleviate a negative mood

- Putting in danger/losing an affectionate relationship/a job/study or career opportunities

- At least 5 of these manifestations over a 12-month period

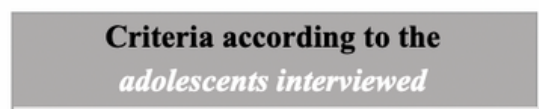

- Daily gaming

- Significant time spent gaming

- Neglecting the real world

- Confusing the virtual world with the real world and transposing certain dangerous acts

- Fewer other activities and isolation

- Can no longer be without video games

-Withdrawal symptoms

- Tolerance

- Cravings

- Significant purchases

Figure 2

Key: Interchangeable criteria are words in bold and italic type in the text. Relationship between the criteria proposed for diagnosing a pathological video games use in accordance with the ICD-11 and DSM- 5 classifications and the criteria suggested by the adolescents interviewed 